\title{
PENGARUH FAKTOR-FAKTOR TEKNIS DAN ORGANISASIONAL TERHADAP PENGEMBANGAN SISTEM PENGUKURAN KINERJA (Studi Pada OPD Kota Pekanbaru)
}

\author{
Gusmarila Eka Putri ${ }^{1}$, Faizah Kamilah ${ }^{2}$ \\ ${ }^{1,2}$ Fakultas Ekonomi Universitas Lancang Kuning \\ Jln. D.I. Panjaitan KM 8 Rumbai Pekanbaru \\ E-mail : gusmarilaputri@unilak.ac.id \\ diterima: 8/9/2018; direvisi: 4/1/2019; diterbitkan: 31/3/2019
}

\begin{abstract}
Based on presidential instruction number 7 of 1999 concerning the performance accountability of government agencies and the Decree of the Head of the State Administration Agency (LAN) No.589 / IX / 6 / Y / 1999 concerning Guidelines for Preparation of Performance Accountability Reports of Government Agencies, which have been improved by LAN Decree Number 239 / IX / 6/8/2003. In 2006 the government issued another regulation that supports the implementation of a performance measurement system in Indonesia, namely PP RI No. 8 of 2006 concerning Financial Reporting and Performance of Government Agencies. Next is PERMENPAN RB No. 29 of 2010 concerning Guidelines for Preparing AKIP Performance and Reporting. The issuance of PP RI Number 8 of 2006 and PERMENPAN RB Number 29 of 2010 shows the government's seriousness in improving the performance of government organizations and encourages the development of performancebased management in Indonesia. But in fact, the ability of a performance measurement system to improve performance, transparency and performance accountability of government agencies (AKIP) is still often debated or questioned. This situation is quite reasonable because some research results still indicate a problem in the implementation of a performance measurement system. Problems arise at the stage of developing a performance measurement system as well as at the stage of using the results of implementing a performance measurement system. This study aims to examine several factors that influence the development of a performance measurement system in Pekanbaru City OPD. These factors consist of technical and organizational factors. Technical factors include the limitations of information systems, and organizational factors include management commitment, decisionmaking authority, and organizational culture. This research was conducted using a survey method by distributing questionnaires to echelon 2, 3, and 4 officials who were involved and responsible for the preparation of the Strategic Plan and Lakip in the OPD of Pekanbaru City. With the purposive sampling method, then the data analysis was performed using multiple regression analysis. The results of this study found that the limitations of information systems were not proven to have a negative effect on the development of performance measurement systems, management commitment, decision-making authority, and organizational culture proved to have a positive effect on the development of performance measurement systems.
\end{abstract}

Keywords: Development of Performance Measurement Systems, Technical Factors, Organizational Factors

\section{PENDAHULUAN}

Beberapa kondisi yang diakibatkan oleh krisis ekonomi dan kepercayaan telah membuat pemerintah semakin berupaya untuk memperbaiki kinerjanya. Kondisi tersebut antara lain, adanya citra buruk terhadap birokrasi Pemerintah Indonesia, bahwa kinerja birokrasi senantiasa dikaitkan denga segala sesuatu yang serba lamban dan berbelit-belit serta formalitas. Dalam penyelesaian urusan kinerja birokrasi selalu mendapatkan hambatan yang memakan waktu, sehingga selalu tertunda penyelesaiannya.

Dilihat dari sisi kinerja, berdasarkan penelitian yang dilakukan oleh Indonesia Governance Index (IGI) pada tahun 2014 yang dilakukan pada 34 provinsi di seluruh Indonesia 
menunjukkan rata-rata nasional kinerja tata kelola pemerintahan provinsi hanya mencapai angka 5,70 dari skala 1 sampai 10. Dan provinsi Riau sendiri menempati urutan ke delapan dengan capaian indeks 6,18, padahal nilai yang bagus menurut IGI adalah $7,8 \mathrm{ke}$ atas (IGI, 2014).

Dalam hal pelayanan publik, khususnya terkait kepatuhan unit pelayanan publik pemerintah daerah terhadap UU pelayanan publik menunjukkan standar pelayanan di 55 pemerintah kota menunjukkan Kota Pekanbaru masuk dalam zona kuning, yang artinya predikat kepatuhan sedang (Ombudsman RI, 2017)

Berdasarkan laporan Ombudsman RI perwakilan Riau, ada dua satuan kerja Pemerintah Kota Pekanbaru, masing-masing Dinas Bina Marga dan Dinas Tata Ruang dan Bangunan, mendapat rapor merah pada tahun 2016 . Namun ada juga satuan kerja yang melakukan perbaikan kinerja, seperti Disperindag. Tahun 2015 itu masuk zona merah dan untuk tahun 2016 masuk zona hijau (Ombudsman RI, 2017).

Penilaian dari hasil survei di atas tidak terlepas dari semakin meningkatnya kesadaran masyarakat terhadap penyelenggaraan pemerintahan memicu timbulnya gejolak yang berasal dari ketidakpuasan terhadap pertanggungjawaban yang diberikan oleh penyelenggaraan negara atas kepercayaan yang telah diamanatkan rakyat. Oleh karena itu, hal ini merupakan salah satu alasan yang akhirnya mendorong peningkatan kebutuhan adanya suatu pengukuran kinerja terhadap penyelenggaraan negara. Bahasan tentang pengukuran kinerja pada sektor publik telah mendapat perhatian para peneliti. Norman (2010) berpendapat bahwa melalui pengukuran kinerja, keberhasilan satuan organisasi/kerja akan lebih dilihat dari kemampuannya, berdasarkan sumber daya yang dikelolanya, untuk mencapai hasil sesuai dengan rencana yang telah dituangkan dalam rencana stratejik. Jadi, dengan mengimplementasikan sistem pengukuran kinerja diharapkan dapat membantu memperbaiki kinerja pemerintah dalam mewujudkan tujuan dan sasaran, efisiensi, dan efektivitas layanan publik secara transparan, membantu alokasi sumber daya dan pembuatan keputusan, serta mewujudkan pertanggungjawaban publik.

Namun faktanya, kemampuan sistem pengukuran kinerja untuk meningkatkan kinerja, transparansi, dan akuntabilitas kinerja instansi pemerintah (AKIP) masih sering diperdebatkan atau dipertanyakan. Situasi ini cukup masuk akal karena beberapa hasil penelitian memang masih menunjukkan adanya masalah dalam implementasi sistem pengukuran kinerja. Permasalahan muncul pada tahap pengembangan sistem pengukuran kinerja maupun pada tahap penggunaan hasil dari implementasi sistem pengukuran kinerja (Nurkhamid, 2008). Laporan Menpan dan Reformasi Birokrasi mengenai hasil evaluasi akuntabilitas kinerja pemerintah kabupaten/kota tahun 2016 adalah 49,87, hasil ini mengalami peningkatan 2,95 poin dari tahun 2015 yang hanya 46,92. Walaupun begitu, rata-rata kabupaten/ kota pada tahun 2016 masih di bawah 50, yang artinya masih berada pada kategori C. Rendahnya tingkat akuntabilitas ini dikarenaka empat masalah utama, yakni tujuan/sasaran yang ditetapkan tidak berorientasi pada hasil, ukuran keberhasilan tidak jelasa dan terukur, program yang ditetapkan tidak berkaitan dengan sasaran, dan rincian kegiatan tidak sesuai dengan maksud kegiatan (MENPAN RB, 2017).

Agar implementasi sistem pengukuran kinerja dapat berhasil, maka perlu dicari akar permasalahannya. Kwon \& Zmud, 1987 dan Shield \& Young (2003) dalam Nurkhamid (2008) 
Jurnal Ilmiah Ekonomi dan Bisnis

Vol. 16. No.1, Maret 2019: 10-18

EISSN : $2442-9813$

ISSN : $1829-9822$

mengungkapkan beberapa faktor yang mempengaruhi pengembangan sistem pengukuran kinerja, yang meliputi faktor organisasional dan teknik. Faktor organisasional meliputi komitmen manajemen untuk menggunakan informasi kinerja, otoritas pembuatan keputusan yang didelegasikan pada pengguna informasi kinerja, dan pelatihan berbagai teknik yang berkaitan dengan implementasi sistem pengukuran kinerja. Sedangkan faktor teknis meliputi kesulitan menentukan ukuran kinerja pada beberapa kebijakan/ progam/kegiatan yang sulit diukur serta keterbatasan sistem informasi yang dimiliki oleh organisasi untuk memberikan data yang valid, reliable, tepat waktu dan dengan cara yang efektif. Secara khusus, Sihaloho (2005) menyatakan bahwa implementasi sistem pengukuran kinerja yang akan membawa perubahan dalam organisasi juga akan menuntut perubahan perilaku personil organisasi dan menuntut kesiapan organisasi, baik sumberdaya manusia, teknologi maupun budaya organisasi.

Oleh sebab itu, penelitian ini disusun dalam rangka untuk membuktikan beberapa faktor yang diduga mempengaruhi pengembangan sistem pengukuran kinerja.

\section{TINJAUAN PUSTAKA}

Sistem adalah sekumpulan sumber daya yang saling terkait untuk mencapai tujuan (Bodnar, 2006). Pengukuran kinerja didefinisikan sebagai proses untuk mengkuantifikasi efisiensi dan efektivitas dari suatu tindakan (Cocca dan Alberti, 2010). Tindakan yang dimaksud adalah tindakan masa lalu. Pengukuran kinerja adalah bagian dari analisa atau diagnosa terhadap proses untuk mengidentifikasi aktivitas mana yang diprioritaskan untuk diperbaiki. Sehingga sistem pengukuran kinerja adalah seperangkat bagianbagian yang saling berhubungan erat satu dengan yang lainnya yang bertujuan untuk menilai secara periodik efisiensi dan efektivitas operasional instansi pemerintah serta menilai keberhasilan/ kegagalan pelaksanaan program/ kebijaksanaan sesuai dengan sasaran dan tujuan yang telah ditetapkan.

Sistem pengukuran kinerja perlu dikembangkan guna mendukung pemerintah meningkatkan kinerjanya dalam rangka memberikan pelayanan publik yang lebih baik. Sehingga pengembangan sistem pengukuran kinerja yang terkait dengan penelitian ini adalah proses pengumpulan ukuran kinerja yang dilaporkan secara teratur melalui sistem informasi suatu instansi pemerintah. Dengan demikian, pengembangan sistem pengukuran kinerja tercerminkan dengan adanya pengembangan berbagai ukuran kinerja yang akan digunakan oleh suatu organisasi.

Kwon \& Zmud, 1987 dan Shield \& Young (2003) dalam Nurkhamid (2008) mengungkapkan beberapa faktor yang mempengaruhi pengembangan sistem pengukuran kinerja, yang meliputi faktor organisasional dan teknik. Faktor organisasional meliputi komitmen manajemen untuk menggunakan informasi kinerja, otoritas pembuatan keputusan yang didelegasikan pada pengguna informasi kinerja, dan pelatihan berbagai teknik yang berkaitan dengan implementasi sistem pengukuran kinerja. Sedangkan faktor teknis meliputi kesulitan menentukan ukuran kinerja pada beberapa kebijakan/progam/kegiatan yang sulit diukur serta keterbatasan sistem informasi yang dimiliki oleh organisasi untuk memberikan data yang valid, reliable, tepat waktu dan dengan cara yang efektif.

Keterbatasan sistem informasi merupakan keadaan dimana sistem informasi memberikan keterbatasan untuk memberikan data yang dibutuhkan oleh pengguna informasi (Norman, 2010). Beberapa penelitian di sektor publik 
mengindikasikan bahwa masalah sistem informasi menggambarkan hambatan utama dalam kesuksesan implementasi sistem pengukuran kinerja dalam meningkatkan akuntabilitas kinerja. Masalah ini berhubungan dengan keterbatasan kemampuan sistem informasi yang ada untuk memberikan data yang reliabel, valid, tepat waktu dan dengan biaya yang efektif (Nurkhamid, 2008).

Dalam konteks implementasi sistem pengukuran kinerja, Shields (Nurkhamid, 2008) menyatakan bahwa komitmen manajemen dapat dicerminkan dengan mengalokasikan sumber daya, tujuan, dan strategi pada berbagai rencana yang dianggap bernilai, menolak sumber daya yang menghambat inovasi, dan memberikan dukungan politis yang diperlukan untuk memotivasi atau menekan para individu atau pihak lain yang menolak keberadaan inovasi.

Pengambilan

keputusan didefinisikan sebagai proses memilih diantara berbagai alternatif tindakan yang berdampak pada masa depan (Lubis, 2011). Dengan adanya pendelegasian otoritas pengambilan keputusan maka dapat membantu manajemen untuk dapat mengambil keputusan dengan lebih cepat, menumbuhkembangkan kreatifitas dan usaha dalam melakukan suatu perubahan. Selain itu juga dapat meningkatkan akuntabilitas diantara personil organisasi sektor publik. Setiap bawahan yang diberi otoritas untuk mengambil keputusan dan bawahan tersebut harus mempertanggungjawabkan keputusan yang diambil untuk mencapai target yang telah ditentukan sebelumnya. Sehingga dengan pendelegasian otoritas pengambilan keputusan dari pimpinan kepada bawahan dalam instansi pemerintah dapat membantu organisasi tersebut untuk meningkatkan kinerjanya.
Menurut Sudarmadi (2007) budaya organisasi merupakan kebiasaan yang berlaku pada organisasi. Dalam penelitian ini, budaya organisasi direfleksikan dengan sikap keterbukaan organisasi terhadap perubahan dan inovasi (yaitu sistem pengukuran kinerja). Menurut Nurkhamid (2008) sikap organisasi ini dapat dinilai dengan keberadaan sistem reward yang menghargai inovasi dan pengambilan resiko dalam suatu organisasi serta dengan mengevaluasi persepsi dan perilaku pimpinan dan stafnya terhadap inovasi dan perubahan

\section{METODE PENELITIAN}

Populasi penelitian adalah dinas dan badan pada OPD Kota Pekanbaru yang hasil penilaian kinerjanya pada tahun 2016 menurut Lembaga Ombudsman mendapat rapor atau zona hijau, yaitu Dinas Penanaman Modal dan Pelayanan Terpadu Satu Pintu, Dinas Perindustrian dan Perdagangan, Dinas Perhubungan, dan Badan Perpustakaan dan Arsip.

Responden penelitian adalah pejabat Eselon II, Eselon III, dan Eselon IV pada dinas dan badan yang terlibat dan bertanggungjawab dalam penyusunanan RENSTRA dan LAKIP pada OPD di Pemerintah Kota Pekanbaru. Pemilihan sampel penelitian ini di dasarkan pada metode purposive sampling dimana sampel yang dipilih berdasarkan kriteria/pertimbangan tertentu (Sugiyono, 2012).

Pengumpulan data primer dari responden dilakukan dengan metode survei, yaitu dengan cara mengumpulkan data primer dari suatu sampel dengan menggunakan instrumen kuesioner dengan cara memberikan daftar pernyataan tertulis kepada responden secara langsung dengan mendatangi dinas dan badan pada OPD Kota Pekanbaru.

Pengujian instrument penelitian dilakukan dengan tujuan memperoleh data yang berkualitas (goodness of data). 


\section{Jurnal Ilmiah Ekonomi dan Bisnis}

Vol. 16. No.1, Maret 2019: 10-18

EISSN : $2442-9813$

ISSN : $1829-9822$

Pengujian ini mencakup uji validitas dan uji reliabilitas. Uji validitas menggunakan correlate bivariate antara tiap skor item pernyataan dengan skor total variable, sedangkan uji reliabilitas menggunakan coefficient cronbach's alpha.

Pengujian asumsi klasik yang digunakan dalam penelitian ini adalah uji normalitas, uji linearitas, uji multikolinearitas, dan uji heteroskedastisitas. Sedangkan untuk pengujian hipotesis dengan menggunakan analisis regresi berganda. Regresi berganda digunakan untuk menguji pengaruh dua atau lebih variabel independen terhadap variabel dependen (Ghozali, 2011). Persamaan regresi berganda dalam penelitian ini adalah:

Persamaan regresi:

$Y_{1}=\beta_{0}+\beta_{1} X_{1}+\beta_{2} X_{2}+\beta_{3} X_{3}+\beta_{4} X_{4}+\varepsilon$

Keterangan:

$\mathrm{Y}_{1}=$ Pengembangan sistem pengukuran kinerja

$\beta_{0}=$ Konstansta

$\beta_{1-4}=$ Slope

$\mathrm{X}_{1}=$ Keterbatasan sistem informasi

$\mathrm{X}_{2}=$ Komitmen manajemen

$\mathrm{X}_{3}=$ Otoritas pengambilan keputusan

$\mathrm{X}_{4}=$ Budaya organisasi

$\varepsilon=$ Error

\section{HASIL DAN PEMBAHASAN}

Penelitian ini menggunakan data yang diperoleh dari penyebaran kuesioner kepada empat OPD yang mendapat peringkat zona hijau dari Ombudsman sebagaimana yang telah dijelaskan pada bab sebelumnya. Dari 64 total jabatan pejabat tingkat eselon 2, 3, dan 4 di empat OPD, sejumlah 46 kuesioner yang dapat dianalisis lebih lanjut $(71,87 \%)$.

Pengujian validitas dilakukan dengan menghitung korelasi antara skor item instrument dengan skor total. Nilai koefisien korelasi antara skor setiap item dengan skor total dihitung dengan analisis corrected item-total correlation. Selanjutnya teknik yang digunakan untuk mengukur tingkat reliabilitas adalah cronbach alpha dengan cara membandingkan nilai alpha dengan standarnya. Koefisien cronbach alpha yang lebih dari 0,60 menunjukkan keandalan (reliabilitas) instrument. Berdasarkan hasil uji, disimpulkan bahwa semua variabel penelitian valid dan reliabel untuk digunakan dalam penelitian ini (data ada pada peneliti).

Pada penelitian ini, pengujian normalitas data dapat dilihat dari normal probability plot. Data menyebar di sekitar dan mengikuti garis diagonal. Jadi, dapat diartikan bahwa model regresi memenuhi asumsi normalitas.

Uji multikolinearitas dilakukan untuk menguji apakah di dalam model regresi ditemukannya adanya korelasi antar variabel bebas (independen). Untuk mendeteksi ada tidaknya multikolinearitas didalam regresi dapat dilihat dari nilai torelance dan nilai Variance Inflasing factor (VIF). Pedoman suatu model regresi yang bebas multikolinieritas adalah nilai besaran Variance Inflation Faktor (VIF) $<10$ dan Tolerance $>0,10$, diperoleh nilai VIF untuk seluruh variabel bebas $<10$ dan tolerance $>0,10$. Hal ini dapat disimpulkan bahwa model regresi tersebut bebas dari multikolinearitas.

Salah satu cara untuk mendeteksi heteroskedastisitas adalah dengan melihat grafik scatterplot dengan menggunakan aplikasi SPSS. Jika ada titik pola tertentu yang teratur (bergelombang, melebar kemudian menyempit) maka mengindikasikan telah terjadi heteroskedastisitas. Jika tidak ada pola yang jelas, serta titik-titik menyebar diatas dan dibawah angka 0 pada sumbu Y, maka tidak terjadi heteroskedastisitas (Ghozali, 2011), terlihat titik-titik menyebar secara acak, tidak membentuk suatu pola tertentu yang jelas, serta 
tersebar di atas dan di bawah angka 0 . Oleh karena itu dapat dikatakan model regresi dalam penelitian ini bebas dari heteroskedastisitas.

Koefisien determinasi adalah sebuah koefisien yang menunjukkan persentase semua pengaruh variabel independen dan variabel moderating terhadap variabel dependen.

$$
\text { Dari hasil pengujian }
$$

menunjukkan bahwa nilai $\mathrm{R}$ Square sebesar 0,888. Artinya adalah bahwa sumbangan pengaruh variabel bebas terhadap variabel terikat adalah sebesar $88 \%$ Sedangkan sisanya $12 \%$ dipengaruhi oleh variabel lain yan tidak dimasukkan dalam model penelitian ini.

Uji keselarasan (Goodness of Fit) dilakukan dengan uji F. Uji F dilakukan untuk melihat apakah koefisien regresi berganda yang didapat dalam model bisa digunakan untuk memprediksi nilai variabel tak bebas yaitu Y.

Dari hasil pengujian terlihat bahwa nilai $\mathrm{F}$ hitung sebesar 81,637 pada tingkat signifkansi 0.000 , artinya dapat dipastikan bahwa $\mathrm{F}$ hitung lebih besar daripada $F$ tabel 2,461. Hal ini menunjukkan bahwa variabel keterbatasan sistem informasi, komitmen manajemen, otoritas pengambilan keputusan, dan budaya organisasi secara bersama-sama berpengaruh signifikan terhadap pengembangan sistem pengukuran kinerja.

Untuk membuktikan apakah hipotesis diterima atau ditolak, maka dilakukan uji regresi linier berganda. Dari pengujian yang dilakukan, diperoleh hasil koefisien regresi dapat dilihat pada tabel berikut.

Berdasarkan hasil analisis regresi, maka persamaan regresi yang terbentuk pada uji regresi ini adalah : $\mathrm{Y}=4,471+0,179 \mathrm{KSI}+0,146 \mathrm{KM}+$ $0,201 \mathrm{OPK}+0,292 \mathrm{BO}+\mathrm{e}$
Keterbatasan Sistem Informasi (X1) Berpengaruh Negatif Terhadap Pengembangan Sistem Pengukuran Kinerja (Y)

Dari tabel coefficient di atas menunjukkan bahwa nilai $t_{\text {hitung }}$ positif sebesar 2,071 dengan signifikansi 0,045 dan diperoleh nilai $t_{\text {tabel }}$ pada taraf signifikansi $5 \%$ (2-tailed) adalah 2,018. Hal ini menunjukkan bahwa keterbatasan sistem informasi tidak terbukti berpengaruh negatif terhadap pengembangan sistem pengukuran kinerja, berarti hipotesis pertama ditolak.

Berdasarkan data yang disajikan dalam statistik deskriptif, dan keterbatasan sistem informasi berpengaruh positif terhadap pengembangan sistem pengukuran kinerja, menunjukkan bahwa OPD Kota Pekanbaru tidak begitu mengalami masalah dengan informasi yang terbatas untuk memberikan data yang reliabel, valid, tepat waktu dan efektif pada saat mengembangkan sistem pengukuran kinerja.

Komitmen Manajemen (X2) Berpengaruh Positif Terhadap Pengembangan Sistem Pengukuran Kinerja (Y)

Dari data coefficient menunjukkan bahwa nilai $t_{\text {hitung }}$ sebesar 2,484 dengan signifikansi 0,017 dan nilai $t_{\text {tabel }}$ adalah 2,018. Dengan demikian diketahui bahwa $t_{\text {hitung }}(2,484)>t_{\text {tabel }}(2,018)$ dan Sig $(0,017)<0,05$. Hal ini menunjukkan bahwa komitmen manajemen berpengaruh positif dan signifikan terhadap pengembangan sistem pengukuran kinerja. Yang berarti hipotesis kedua diterima.

Hasil hipotesis ini sesuai dengan penelitian Cavaluzzo dan Ittner (2003), Laurensius dan Halim (2005), Nurkhamid (2008), Norman (2010), dan Astuti (2011) yang menyatakan bahwa komitmen manajemen terbukti berpengaruh positif 


\section{Jurnal Ilmiah Ekonomi dan Bísnis}

Vol. 16. No.1, Maret 2019: 10-18

EISSN : $2442-9813$

ISSN : $1829-9822$

terhadap pengembangan sistem pengukuran kinerja.

Berdasarkan data yang disajikan dalam statistik deskriptif serta analisis regresi variabel komitmen manajemen berpengaruh positif terhadap pengembangan sistem pengukuran kinerja, menunjukkan bahwa pejabat pemerintah di OPD Kota Pekanbaru telah memiliki komitmen yang kuat untuk mengalokasikan sumber daya seperti dana, SDM, dan waktu untuk digunakan dalam mengembangkan ukuran kinerja

Otoritas Pengambilan Keputusan (X3) Berpengaruh Positif Terhadap Pengembangan Sistem Pengukuran Kinerja (Y)

Menunjukkan bahwa nilai $t_{\text {hitung }}$ sebesar 2,029 dengan signifikansi 0,049 dan nilai $t_{\text {tabel }}$ adalah 2,018. Dengan demikian diketahui bahwa $t_{\text {hitung }}(2,029)$ $>t_{\text {tabel }}(2,018)$ dan $\operatorname{Sig}(0,049)<0,05$. Hal ini menunjukkan bahwa otoritas pengambilan keputusan berpengaruh positif dan signifikan terhadap pengembangan sistem pengukuran kinerja. Dengan demikian hipotesis ketiga diterima.

Hasil pengujian ini mendukung penelitian Nurkhamid (2008), dan Astuti (2011) yang menyatakan bahwa otoritas pengambilan keputusan terbukti berpengaruh positif terhadap pengembangan sistem pengukuran kinerja.

Berdasarkan hasil statistik deskriptif dan hasil uji regresi variabel otoritas pengambilan keputusan berpengaruh positif terhadap pengembangan sistem pengukuran kinerja mengindikasikan bahwa otoritas dan wewenang pejabat pemerintah dalam membuat keputusan yang diperlukan untuk mencapai berbagai tujuan strategis organisasi telah digunakan pada saat mengembangkan ukuran kinerja.

Budaya Organisasi (X4) Berpengaruh Positif Terhadap Pengembangan Sistem Pengukuran Kinerja (Y)

Menunjukkan bahwa nilai $t_{\text {hitung }}$ sebesar 4,028 dengan signifikansi 0,000 dan nilai $t_{\text {tabel }}$ adalah 2,018. Dengan demikian diketahui bahwa $t_{\text {hitung }}(4,028)>$ $t_{\text {tabel }}(2,018)$ dan Sig $(0,000)<0,05$. Hal ini menunjukkan bahwa budaya organisasi berpengaruh positif dan signifikan terhadap pengembangan sistem pengukuran kinerja. Dengan demikian hipotesis keempat ini diterima.

Hasil uji ini mendukung penelitian Nurkhamid (2008), dan Astuti (2011) yang menyatakan bahwa budaya organisasi mempengaruhi pengembangan sistem pengukuran kinerja. Berdasarkan statistik deskriptif dan variabel budaya organisasi yang terbukti berpengaruh terhadap pengembangan sistem pengukuran kinerja menunjukkan bahwa pejabat OPD Kota Pekanbaru telah melakukan inovasi dan perubahan untuk meningkatkan kinerja organisasi. Pejabat pemerintah selaku pimpinan telah memberikan pemahaman kepada stafnya bahwa pengukuran kinerja merupakan alat yang dapat meningkatkan kinerja instansi serta juga disertai dengan pemberian imbalan (reward) atas upaya staf dalam meningkatkan kinerja instansi.

\section{KESIMPULAN DAN SARAN}

Berdasarkan hasil analisis data telah dilakukan dengan menggunakan uji regresi, dapat diketahui faktor-faktor yang mempengaruhi pengembangan sistem pengukuran kinerja di lingkungan OPD Kota Pekanbaru.

Keterbatasan sistem informasi tidak terbukti berpengaruh negatif terhadap pengembangan sistem pengukuran kinerja. Hal ini menunjukkan bahwa kendala yang dihadapi pejabat pemerintah di OPD Kota 
Pekanbaru untuk memperoleh data yang berkualitas (valid, reliabel, dan tepat waktu) tidak menghalangi mereka dalam mengembangkan ukuran kinerja. Komitmen manajemen, otoritas pengambilan keputusan, dan budaya organisasi terbukti berpengaruh terhadap pengembangan sistem pengukuran kinerja.

Bagi peneliti yang akan meneliti topik yang sama agar dapat mengembangkan penelitiannya dengan melihat faktor-faktor lain yang mempengaruhi pengembangan sistem pengukuran kinerja, serta dapat menambah teknik pengambilan data dengan melakukan proses wawancara dan data sekunder yang akan meningkatkan hasil analisis.

Untuk itu, saran kepada instansi pemerintah bahwa untuk selanjutnya agar dapat mengembangkan sistem informasi yang komprehensif dan terintegrasi sehingga data kinerja yang digunakan dalam mengembangkan ukuran kinerja dapat meningkat kualitasnya.

\section{DAFTAR PUSTAKA}

Astuti, Ratih Widya, 2011, Persepsi Terhadap Pengembangan Sistem Pengukuran, Akuntabilitas, dan Penggunaan Informasi Kinerja di Instansi Pemerintah (Studi pada Pemerintah Kabupaten Semarang), Skripsi Fakultas Ekonomi, Universitas Diponegoro

Cocca P, Alberti M. 2010. A Framework to Assess Performance Measurement Sistems in SMEs. International Journal of Productivity and Performance Management 59 (2) : $186-200$.

GAO, 1997a, Managing For Result: Analytic Challenges in Measuring Performance. MD: Gneral Accounting Office,
Gaithersburg, GAO/HEHS/ GGD97-138

Ghozali, I, (2011), Aplikasi analisis multivariate dengan program SPSS, Semarang, Badan penerbit Universitas Diponegoro

IGI,http://www.kemitraan.or.id/igi/index.ph $\mathrm{p}$

Jamil, B. O, 2013, Pengaruh Faktor Teknis \& Faktor Organisasi Terhadap Implementasi Sistem Pengukuran Kinerja (Studi Empiris Pada SKPD Pemerintah Kota Solok), Sumbar: Universitas Negeri Padang

Lubis, Arfan Ikhsan. 2010. Akuntansi Keperilakuan. Salemba Empat. Jakarta

Norman, dan Fachruzzaman, 2010, Implementasi Sistem Pengukuran Kinerja Satuan Kerja Perangkat Daerah (SKPD) di Kota Bengkulu, Simposium Nasional Akuntansi XIII, Purwokerto

Nurkhamid, M, 2008, Implementasi Inovasi Sistem Pengukuran Kinerja Instansi Pemerintah, Jakarta: Jurnal Akuntansi Pemerintah Vol. 3, No. 1 Oktober 2008 Hal. 45-76

Ombudsman RI, 2013, UU Pelayanan Publik, www.ombudsman.go.id (diakses pada 15 Mei 2017)

Peraturan Pemerintah Nomor 8 Tahun 2006 tentang Pelaporan Keuangan dan Kinerja Instansi Pemerintah, Melalui (www.google.com).

Sugiyono, 2012, Metode Penelitian Bisnis, Bandung: CV Alfabeta

Syachbrani, W., dan R. Akbar, 2013, Faktor-Faktor Teknis dan 
Jurnal Ilmiah Ekonomi dan Bísnis

Vol. 16. No.1, Maret 2019: 10-18

EISSN : $2442-9813$

ISSN : $1829-9822$

Keorganisasian

yang

Mempengaruhi Pengembangan

Sistem Pengukuran Kinerja

Pemerintah Daerah. Jurnal Reviu

Akuntansi dan Keuangan Vol. 3

No. 2 (Oktober 2013)

Windayani, Santi, 2008, Analisis Faktorfaktor yang Berpengaruh Terhadap Penggunaan Informasi Kinerja dalam Penganggaran, Jurnal Ekonomi \& Bisnis Vol 2 No. 1, Maret 2008

Yowi, Linda Rambu Kuba, 2013, Hubungan Faktor-Faktor Implementasi, Pengembangan Sistem, dan Hasil Sistem Pengukuran Kinerja (Studi di Pemerintah Daerah Kabupaten Sumba Timur),Fakultas Ekonomika dan Bisnis, Universitas Gadjah Mada
Yuwono, Sony, dkk, 2008, Petunjuk Praktis Penyusunan Balanced Scorecard, Jakarta : Gramedia Pustaka Utama

Pratama, Gian, “Ombudsman Nilai 2 SKPD Pemko Pekanbaru di Zona Merah, Edwar Sanger Segera Lakukan Evakuasi" 19 Februari 2018, http://www.fokusriau.com/beritaombudsman-nilai-2-skpd-pemkopekanbaru-di-zona-merah-edwarsanger-segera-lakukanevakuasi.html

Santoso, Singgih, 2010, Aplikasi SPSS Pada Statistik Multivariat, Elex Media Komputindo, Jakarta. 